gynaecology should be read by all gynaecologists. Again, Chassar Moir sums up his extensive experience on vesicovaginal fistulas in a most valuable manner. Brew's chapter on 'The Vulva' has many excellent photographs and it is pleasing to note that the Editor's chapter on 'The Vagina' keeps well abreast of the other contributors.

These two books, despite their expense, should be bought by all interested in the subject. I am sure their success will justify future editions.

\section{DISEASES OF THE EAR, NOSE AND THRUAT IN CHILDREN}

By T. G. Wilson, M.B., B.Ch., F.R.C.S.I., M.R.I.A. Pp. xii +307 , with 145 illustrations. London: Wm. Heinemann, Ltd. I955. 70 s.

This book makes very pleasant reading. The author has unrivalled experiences in diseases of children and he gives very clearly his opinion and advice on the aetiology and management of many childish ailments. In addition he has quoted very fully from other textbooks and current articles of world literature and the result gives a useful review in one textbook. The author has also borrowed widely many figures and diagrams to augment those beautifully drawn by himself.

Parts of the book give very useful information. Full descriptions are made of the congenital abnormalities in various sites, of the differences between children and adults in anatomy and physiology of various structures such as the eustachian tube, middle ear and larynx. Deafness in children is described at length with the all important stress on the need for early auditory training, before the age of two if possible; lip-reading is, however, only accorded four lines of text. Defective speech is dealt with more fully than in most oto-laryngeal books and sinusitis, nasal allergy, laryngeal defects and neck conditions are well and fully considered.

It is always easy to be critical of other persons' work; everyone is entitled to his own opinion. Some statements appearing in this book, however, do not seem to accord with the general concensus of opinion. Only a few omissions in the text are noticeable, though not enough stress is given to some subjects and too much to some others.

The standard of illustration is high, although the choice of a few appears inappropriate. There seems room for additional diagrams to deal, with such subjects as the tracheostomy operation and the appearances on otoscopy and a need for cutting some, such as with the dissection and guillotining of tonsils.

While enjoying the book and paying tribute to the great interest it gives to the subject, some doubt is felt whether its value will justify the relatively high price charged and whether there is a demand for this type of book. It presupposes considerable knowledge of many aspects of the subject matter and yet goes fully into details on others.

Oto-laryngologists will already have specialized textbooks and articles, trainee specialists will need fuller textbooks anyway and paediatricians and general practitioners may regretfully find so much oto-laryngeal detail in some parts and not enough in others as to make them loathe to do more than skim through it in a library. This would be a pity as the contents are of great importance and much of it certainly needs to be more widely recognized.

I.G.R.

\section{PUBLIC RELATIONS IN MEDICAL PRACTICE}

By James E. Bryan. Pp. xiv +302 . London: Baillière, Tindall and Cox Ltd. 1955. 38s. 6d.

This book is a sincere attempt by a well-informed American layman to guide doctors in their professional relationships. The subjects discussed include the doctor's dealings with his colleagues and with the patient, as well as with the larger community. The burden of the book is a plea for humanity and a spirit of service. For the English reader, it is unfortunate that the best chapters are those which seek to apply these principles to such practical matters as hospital organization and payment of fees; the problems discussed here are mostly peculiar to the American health system.

\section{THE PHYSIOLOGICAL BASIS OF MEDICAL} PRACTICE

By C. H. Best, C.B.E., M.A., M.D., D.Sc., F.R.S F.R.C.P., and N. BURKE-TAYLOR, V.D., M.D., F.R.S., F.R.C.S., F.R.C.P., M.R.C.S., L.R.C.P. Sixth edition. Pp. xiv $+1,358$, with 604 illustrations, 3 in colour. London: Baillière, Tindall $\&$ Cox Ltd. 1955. 91s. 6d.

This edition includes much new material, although the total bulk has been slightly reduced. It will continue to be a popular textbook but nevertheless one could wish for certain improvements. Description of some of the clinical topics (such as the E.S.R.) is out of touch with present medical practice. Electrolyte balance is almost totally neglected and potassium is omitted completely from the list of toxic substances that accumulate in renal failure. References to clinical conditions should be restricted to those which illustrate physiological principles. Some descriptions of original work need to be more precise; thus in the account of Goldblatt's experiment it is important to state that he was working with dogs. The dates of quoted work should be given, especially where there is more than one paper by the same author. The page headings are sometimes anomalous; thus hypertension appears under the heading 'Venous blood flow.' The prose style is not easy to read; punctuation could be improved, some split infinitives re-united and jargon (such as 'osseous tissue' instead of ' bone ') avoided.

These shortcomings should not obscure one's respect for the book as a whole. It emphasizes the basic importance of physiology in clinical medicine and will be useful both to students and to practising clinicians. 